\title{
WAITIN' ON THE GHOST OF TOM JOAD: THE NEOLIBERAL RECONSTRUCTION OF THE DEPRESSION YEARS IN CINDERELLA MAN ${ }^{1}$
}

\author{
FABIÁN ORÁN LLARENA \\ Universidad de La Laguna/Universidad Nacional de Educación a Distancia (UNED) \\ fabian.oran.Ilarena@gmail.com
}

\begin{abstract}
This paper intends to examine the political rationality of neoliberalism through the Depression Era film Cinderella Man (Ron Howard, 2005). While neoliberalism has been widely mapped out, critiqued, and debated in a host of academic disciplines, the myriad forms American film has articulated, represented, and integrated neoliberal narratives remains a largely understudied issue within the field of cultural studies. The present contribution addresses, through a close filmic analysis, the set of discursive strategies by which neoliberalism reenacts and renarrativizes previous ideological, political, and cultural heritages. I argue that Cinderella Man 'neoliberalizes' the Great Depression, highlighting individualism and resilience while totemic questions such as class identity, the legitimacy of deregulated capitalism, and the specific causes and origins of the Depression are rendered either invisible or peripheral. Taking the notion of Gramscian hegemony as the overarching theoretical principle, I draw on a variety of theorists that have inquired into the underpinnings and logics of neoliberal thinking — namely Wendy Brown (2016), Pierre Dardot and Christian Laval (2014), and David Harvey (1990). Thus, the aim of this article is to analyze Cinderella Man as a neoliberal filmic text which significantly departs from the normative ideological, political, and cultural imaginaries historically associated with the Great Depression.
\end{abstract}

Keywords: film studies, neoliberalism, hegemony, resilience, Great Depression. 


\section{Resumen}

Este artículo pretende analizar el neoliberalismo como racionalidad política a través de la película Cinderella Man (Ron Howard, 2005), centrada en la Gran Depresión. A pesar de que el neoliberalismo ha sido ampliamente categorizado, evaluado y debatido en una multitud de disciplinas académicas, existe una importante carencia de estudios culturales que indaguen en las múltiples formas en que el cine estadounidense ha articulado, representado e integrado los relatos del neoliberalismo. El presente trabajo aborda, a través de un exhaustivo análisis fílmico, el conjunto de estrategias discursivas por medio de las cuales el neoliberalismo reconstruye y rearticula narrativamente legados ideológicos, políticos y culturales anteriores. Sostenemos que Cinderella Man 'neoliberaliza' la Gran Depresión, poniendo de relieve el individualismo y la resiliencia mientras que se opacan o minimizan cuestiones centrales como la identidad de clase, la legitimidad del capitalismo desregulado y las causas y orígenes específicos de la Gran Depresión. Tomando la noción de hegemonía Gramsciana como principio teórico sustentante, haremos uso de una serie de teóricos que han investigado las bases y lógicas del neoliberalismo —fundamentalmente Wendy Brown (2016), Pierre Dardot y Christian Laval (2014), y David Harvey (1990). Así, el objetivo de este artículo es analizar Cinderella Man como un texto fímico neoliberal, significativamente escindido de los imaginarios ideológicos, políticos y culturales asociados históricamente a la Gran Depresión.

Palabras clave: estudios fílmicos, neoliberalismo, hegemonía, resiliencia, Gran Depresión.

\section{Neoliberalism, Hegemony, and the New Deal}

To aver that neoliberalism has mutated into a buzzword across politically-minded academic fields would be a gross understatement. What David Harvey originally termed "flexible regime of accumulation", the new paradigm that was to substitute postwar Fordist-Keynesian capitalism (1990: 124), has turned into "a global rationality that operates as a widely shared self-evident verity, pertaining not to a party logic, but to a technique, which is supposedly ideologically neutral, of governing human beings" (Dardot and Laval 2014: 190). ${ }^{2}$ Whether understood as a type of rhetoric, a set of policies or an all-encompassing political rationality, the assumption that increasingly deregulated markets and weakened state structures correlate to enhanced personal freedoms has become, since the 1980s, the starting point for any actor to operate on politics (Brown 2016: 21-31; Harvey 2005: 5-9).

Antonio Gramsci defined hegemony as the ability of a given political force to inscribe its language and principles into political discussion so that all struggles and 
beliefs are conditioned and framed in a way that certain interests and debates are upheld and legitimized while others remain occluded (Gramsci 1991: 181-182). A hegemonic complex makes citizens experience its practices and values as an indistinguishable fact of social life and not as the result of ideological struggles and historical processes which have been naturalized and normalized. Gramsci's hegemony fits the way neoliberalism has morphed into the uncontested, taken-forgranted terrain of politics: "the great ideological victory of neo-liberalism has consisted in 'de-ideologizing' the policies pursued, to the point where they are no longer subject to any debate" (Dardot and Laval 2014: 191). In the US the presidency of George W. Bush (2001-2009) exacerbated many of the most distinctive traits of neoliberalism. The Bush administration consolidated the already-hegemonic policies and vocabularies of deregulated markets, low taxation, and the notion of personal freedoms as being tantamount to a small-scale federal government unable to significantly affect the economy (Formisano 2015: 53-54; Patterson 2010: 122-130; Wilentz 2008: 436-437).

Among the string of films that may prove the hegemonic dimension of neoliberalism in American culture in the 2000s, Ron Howard's 2005 Great Depression Era film Cinderella Man stands as an extremely significant example. Relying on an interdisciplinary cultural studies approach, I argue that Howard's reimagining of the Depression years is articulated on the basis of two key premises. The film, on the one hand, reconstructs the Great Depression featuring a set of discursive lines largely akin to modern-day neoliberal narratives about the individual, the state, and their political independencies —or lack thereof. On the other, Howard's vision of the Great Depression resorts to filmic, cultural, and political legacies ingrained in American history that, although not neoliberal in origin, buttress neoliberal rationality. In so doing, the film fails to engage with the contents and ethos of the New Deal and the liberal progressivism of Franklin D. Roosevelt. ${ }^{3}$

Prior to the McCarthyist turn of the late 1940s, Hollywood produced during the 1930s and 1940s a range of socially conscious films that indicted the excesses of unregulated capitalism. "With the changes inaugurated by the New Deal [...] Hollywood manifested a growing liberal sensibility. In contrast to their bosses, a host of writers, directors and stars associated themselves with its progressive reforms and campaigned for Roosevelt" (Wheeler 2016: 46). Filmmakers such as Robert Rossen, John Ford, King Vidor or Frank Capra addressed some of the very same problems tackled by the policies of the New Deal - namely abusive monopolies, class asymmetries or collusion between economic and political elites (Coma 2007: 41-42). Yet, the political messages of their films, albeit often quite critical, systematically fell within the scope of the institutions, values, and traditions of American democracy and capitalism (Junco Ezquerra 2003: 66-68). One 
quintessential film within that progressive tradition is John Ford's The Grapes of Wrath (1940). The film encapsulates the core common-sense ideas informing the New Deal as both a programmatic policy project and an all-encompassing discourse for the nation. Those ideas could be broadly summarized as follows: that economic markets were at best imperfect, that government action ought to regulate those imperfections, the need for capitalism to be reconfigured in order to halt both extreme inequalities and rebellions, and the notion that organized labor had to play a role in the economic structure (Badger 1989: 118-119; Wells 2003: 6; Zinn 2003: 392). Although this paper is not a comparative analysis of Cinderella Man and The Grapes of Wrath, I will occasionally bring in the latter to the discussion to strengthen some of my arguments. Since The Grapes of Wrath is the paradigmatic New Deal-inspired film, I think it useful to incorporate it as a means to clarify how Cinderella Man downplays and reinterprets some crucial themes of the political culture of the Great Depression.

\section{The Neoliberal Self as Great Depression Hero}

Set in the hardest years of the Great Depression, Cinderella Man follows the comeback story of Jim Braddock (Russell Crowe). A well-established boxer in the late 1920s, Braddock and his family are driven into poverty by the meltdown of the American economy. As the plot unfolds, Braddock will make his way to the top again defeating seasoned and younger boxers - while simultaneously working as a longshoreman - and eventually becoming the heavyweight champion against all odds.

The Great Depression wrecked the legitimacy of classical laissez-faire economics across the industrialized world (Hobsbawm 1994: 94-95). American politics metabolized a number of elements that had not been particularly prominent or seen as legitimate in mainstream public discourse. The Great Depression, writes Seymour Lipset,

undermined traditional American beliefs among large sectors of the population [and] led to the acceptance by a majority of the need for state action to reduce unemployment, to assist those adversely affected by the economic collapse, and to support trade unionism. Analyses of public opinion polls and election results noted that class factors had become highly differentiating variables. (1996: 97)

Cinderella Man transmutes that cultural and sociopolitical landscape into a Horatio Alger storyline: social distress is straightened out by one individual's relentless resolve and will. A noteworthy sequence at the beginning may be illustrative of the film's overall perspective on class, individualism, and the 
historical context of the Great Depression. After introducing Braddock as a successful and well-off man living in the suburbs, there is a shot of him taking off his wristwatch in his bedroom (mins. 7-8). The camera then slowly tracks leftwards into darkness only to show Braddock again, just a few seconds later, visibly poverty-stricken in a clearly different setting in 1933. The way editing and mise-en-scène are deployed in the scene makes it seem as if the camera had literally tracked into the future switching from 1928 to 1933 without cutting. The Great Depression is thus rendered an unexplained catastrophic event, not attributable to concrete agents — and will remain so for the rest of the film. That kind of ahistoricism is, of course, not uncommon in American film. ${ }^{4}$ However, initiating the film with such a marked narrative ellipsis foreshadows the fact that the story will largely skip wide-scope historical perspectives or inquiries into whether systemic or structural factors played a role in the Great Depression.

Still, Cinderella Man is no outlier in representing the Great Depression in that particular fashion. As film scholar Andrew Bergman notes, clusters of films during the Great Depression either celebrated individualism and upward mobility or deflected any questioning of them - e.g. the early 1930s gangster films (1971: 6-7), the "topical films" by director William Wellman (Bergman 1971: 96-97), or Capra's insistence on classlessness in his 1934-1941 cycle (Bergman 1971: 147). What all those films attempted to do — as does Cinderella Man - is to tap into cherished cultural and political values of the American self. "The emphasis in the American value system, in the American Creed" writes Lipset "has been on the individual [...] America began and continues as the most antistatist, legalistic, and rights-oriented nation" (1996: 20). In choosing that specific political and ideological background though, Cinderella Man mutes a significant array of other influences. In his study of the American boxing film, Leger Grindon argues that "the rise of the boxing film in the 1930s coincided with the failure of the market system during the Depression. As a result, the boxing film presented an evolving critique of the American success ethic" (2011: ch. 3). Moreover, as the boxing film came of age during 1930s and early 1940s, conventions and conflicts were introduced carrying "New Deal values that invested the genre with a fresh political attitude" (Grindon 2011: ch. 2). Those elements - potentially quite pertinent for the story of Cinderella Man - are all but absent in the film which, as will be later examined, pays lip service to the politics of the New Deal. The narration systematically and uncritically zeroes in on the individualist dimension of the story and its historical context, with the class struggles of the 1930s and the subsequent four decades of hegemonic Keynesian liberalism playing a rather marginal role in the political disclosure of the film. In so doing, a host of filmic-political legacies specifically linked to the film's historical context remain untapped - the cynicism, disillusionment, and 
preoccupation with corruption of the early 1930s political films (Bergman 1971: 18; Christensen 1987: 31); the communal messages of Our Daily Bread (Vidor 1934) and The Grapes of Wrath; the rhetoric of the Popular Front as portrayed, for instance, in John Ford's 1939 trilogy (Morgan 2016: 260); or the overarching representation in many films from the 1930s of the federal government as a protecting and justice-delivering entity (Bergman 1971: 169).

Underpinned by a filmic and political standpoint that dispenses with class struggles and the questioning of excessive individualism, it is not surprising that Cinderella Man presents a silenced body of workers. At several moments in the film, Braddock goes to the docks along with many other men to be randomly picked up for shifts as longshoreman. In all of these sequences the masses of workers are depicted as an impersonal background rabble, as consequential and functional to the narration as the décor or the setting (Howard 2005: min. 13). The disgruntled and impoverished American society serves as the backdrop against which the protagonist's story is laid out, but no meaningful agency is granted to the working class. The only images portraying communal comradeship among workers appear when Braddock's fights are broadcast on the radio (min. 58). A very telling sequence before the climax shows a long shot of a church full of people praying for Braddock to win the final fight: "They all think that Jim is fighting for them" (min. 107). The masses, the film indicates, only rally once there is a sense of individual heroism that sparks and incites them to come together. However, such galvanization is not to be carried out collectively or by means of social protest, but through adherence to a heroic figure. The ideological background in these sequences is far less attuned to the political culture prevalent throughout the 1930s than to the neoliberal ontology of the individual famously summarized by Margaret Thatcher in her 1987 remark: "There is no such thing as society. There are individual men and women, and there are families. And no government can do anything except through people, and people must look to themselves first" (Thatcher 1987). The Great Depression is transformed into a heroic individual struggle in which socioeconomic difficulties are finally overcome through hard work and sacrifice - any question as to whether unadulterated and deregulated capitalism might be a system prone to inequality is entirely deflected. Political theorist Wendy Brown has seen this type of individualist atomization as being deeply imbricated into the very rationality of neoliberalism as a form of governance:

[W] hen everything is capital, labor disappears as a category, as does its collective form, class, taking with it the analytic basis for alienation, exploitation, and association among laborers. Dismantled at the same time is the very rationale for unions, consumer groups, and other forms of economic solidarity apart from cartels among capitals. [...] The transformation of labor into human capital $[\ldots]$ obscures the visibility and iterability of class. $(2016: 38,65)$ 
Notwithstanding, as mentioned earlier, the existence of certain Great Depression films sanctioning individualism, the film's insistent call for individual effort even disregards the ruminations typical of the boxing film on the Horatio Alger myth — the boxer being both an embodiment and a critique of it (Grindon 2011: ch. 1). Braddock undoubtedly personifies the Horatio Alger myth but at no point does the film really gauge whether that is sustainable or sensible social practice. In this sense, Cinderella Man is patently more ideologically conformist than its 1930s and 1940s genre counterparts, as such films incorporated elements leading to a critical approach of capitalism as part of "the New Deal ethos suspicious of capital and wary of the market opportunities" (Grindon 2011: ch. 2).

On that note, I contend that the individualism fashioned in Cinderella Man, much as it may arguably be linked to classical individualisms of the likes of Jefferson or Tocqueville, is ultimately neoliberal. Braddock's strictly individualistic quest is narrated while simultaneously downgrading issues of social justice and working class mobilization, thereby working against the association of the Great Depression with an indictment of financial greed, the surge of class warfare, and the figure of the state as a functional political actor. It is a form of individualism intrinsically at odds with the political hegemony incipient at that historical point. Neoliberalism certainly draws thematically and philosophically on previous forms of classical liberalism. Thus, some fundamental tenets of neoliberal thought may actually be revisions or reformulations of long-standing principles of former liberalisms, given the "malleability of liberal ideology" (Freeden 2015: 24). In other words, individualism, for instance, is part of the lexicon of neoliberalism as it is of other traditions within classical liberalism. However, from the vast repertoire of existing liberalisms, neoliberalism has retrieved forms of economic and social libertarianism and free market orthodoxy associated with figures such as Ludwig von Mises or F.A. Hayek. "In terms of liberal morphology" writes Michael Freeden, "neoliberals confine the core liberal concept of rationality to maximizing economic advantage" (2015: 109). In so doing, preoccupations informing the history of liberal thought such as the provision of minimum standards of material well-being for freedom to be actualized or the necessity of removing hindrances curtailing human growth (Freeden 2015: 43-48) are conspicuous by their absence in neoliberalism. And so are such elements missing in Cinderella Man. By ignoring the politically-minded aspects of the Depression Era boxing film, by eschewing a critical examination of Horatio Alger-like individualism, and by disregarding key political byproducts of the Great Depression (e.g. the role of the state, class mobilization, a critique of free market orthodoxies), the film seems solidly anchored in the present-day cultural and political hegemony of neoliberalism. 


\section{Good Boxer vs. Bad Activist}

The neoliberal narrative by which class holds a peripheral position is most clearly articulated through the character of Mike Wilson (Paddy Considine). Portrayed as a radicalized and unbalanced man, he is the only direct reference to workers' mobilization and unionization in the film. Mike's reckless and unstable character is repeatedly contrasted with Braddock's abnegation and sense of sacrifice. The following exchange is a good example of it:

MIKE: You know, there's people living in shacks in Central Park. Call it the Hooverville. This government's dropped us flat. We need to organize, you know? Unionize. Fight back.

BRADDOCK: Fight? Fight what? Bad luck? Greed? Drought? No point punching things you can't see. No, we'll work a way through this. FDR, he's gonna handle it. MIKE: Screw FDR. FDR, Hoover, they're all the same. I stand in my living room and between the mortgage and the market and the goddamn lawyer that was supposed to be working for me it stopped being mine. It all stopped being mine. FDR ain't given me my house back yet. (Howard 2005: min 31)

Braddock seemingly "depoliticizes" the historical context, which is per se a considerably politicized take on the ongoing social conflict. On the one hand, Braddock sees labor organization as too much of an abstract and futile battle. On the other, he addresses the causes of the economic downturn as if they were inevitable or, at least, as if it were impossible to insert those in an interpretative scheme where such causes may be ascribed to specific practices and arrangements. Further into the story, Braddock will restate such a perspective through a clear-cut metaphor claiming that, as opposed to real life, in the ring at least he knows who is hitting him (Howard 2005: min. 66). The miseries of the Great Depression are thought of as an act of God whose causes remain unbeknownst to the population -in a manner reminiscent of the opening sequence jumping from pre-Depression America to 1933. The protagonist here indulges in what Gramsci called a fetishist reading of politics, a view by which society functions by itself, attached to no specific actors or material agents (Díaz Salazar 1991: 146-147).

The way Braddock reacts to Mike's class-consciousness strengthens the notion that crises are not to be thought of as windows of opportunity to intervene on structural malfunctioning, but as conjunctures demanding abnegation and sacrifice. "During the cold war $[\ldots]$ ", writes Eric Cazdyn, "to speak the language of disaster and crisis was at once to speak the language of revolution: the discourse could easily slip into revolution. Disaster and crisis were truly dangerous" (2007: 649). Cinderella Man articulates, however, the political conflicts of the 1930s deploying "the anti-revolutionary discourses associated with the post-cold war moment" (Cazdyn 2007: 660), with the end-of-history thesis of Francis Fukuyama (2012), 
whereby crises may indeed provoke some turmoil but are not conducive to structural or significant changes. In this sense, Braddock ultimately personifies the "responsibilized individual" of neoliberalism, a political subject expected to appropriately react to any type of market disruption and "required to provide for [himself] in the context of powers and contingencies radically limiting [his] abilities to do so" (Brown 2016: 134).

The underlying premise of the conflict between Braddock and Mike, where the former is a fair-minded citizen and the latter a pessimistic agitator, is consistently legitimized throughout the film. We are shown Mike is an irresponsible drunkard, unable to provide for his family and solely focused on activism (Howard 2005: mins. 45-46). He ends up dying trying to get people organized in a Hooverville after being fired due to his constant talk about workers' rights (mins. 85-87). In the fashion of a cautionary tale, this subplot fosters the idea that it is not through political contestation and class warfare that American citizens should make sense of their society, as Mike's death warns us. Moreover, if Braddock is to be seen as the representation of the neoliberal "virtuous citizen", willing to tackle problems and thrive in society despite economic meltdown, Mike incarnates the "bad citizen" - a surrogate for "intransigent labor unions" — who remains unable to adapt to market needs (Brown 2016: 212). These ideological elements also water down the more psychologically and politically complex staples of the boxing film. "Cinderella Man", as Grindon bluntly puts it, "is distinctive for turning the boxer into a saint" (2011: Epilogue). He elaborates on that thesis by claiming that

[w] hile Mike Wilson expresses criticism of the success ethic [...] Jim never cries out against injustice and responds only with sensitivity to the hardships endured by his family. Braddock embodies an ideal from the film's opening moments. The hero only needs to await his justified and inevitable recognition. Such a saintly protagonist leaves aside the problems that generate and sustain film genres. (2011: Epilogue)

Grindon's contention may be explained on the grounds that the narration overemphasizes the immaculately good, all-American character of Braddock while sidestepping more critical views on the Great Depression and fashioning an ambiguous position as regards the New Deal, as will be later analyzed. I would argue that presenting such a characterization of Braddock as key components of the New Deal and the marginalization of the critical elements of the boxing film indicate the extent to which the film draws on neoliberalism and its rejection of class and the welfare state.

Even the very narrative-ideological usage of the Hooverville in the plot reinforces to a greater extent the legitimacy of neoliberal rationality. In Cinderella Man the Hooverville is presented through a brief and visually shadowy sequence - with 
menacing point-of-view shots interspersed - which superficially shows rioting and random violence. The sequence functions to further dismantle the idea of class solidarity through Mike's demise and the representation of the Hooverville as a symbol of extreme social decay. In contrast to that depiction, the famous Hooverville sequences in The Grapes of Wrath (mins. 64-75) explicitly zero in on social marginalization and economic and police wrongdoing, as well as on the need for workers to organize. In a dramatic exchange, one corrupt policeman in connivance with a business contractor tries to arrest a man who, suspicious of the latter's intentions, asks him about the wages he intends to pay. When trying to intimidate and arrest the man for merely posing the question, Tom Joad (Henry Fonda) and Casy (John Carradine) hit the policeman and let the man go free. Whereas the Hooverville stands as a mere placeholder for social violence and disintegration in Cinderella Man, Ford uses it to represent certain forms of class empathy and solidarity as defense strategies against inequality and institutional corruption. The very visual styles used to reconstruct the Hooverville in both films are also palpably different. Ford shows it for the first time through an unvarnished point-of-view long take of the Joads in their van entering the overcrowded Hooverville as the families camped there stare at them. The scene is extremely naturalistic and matter-of-fact in visual terms. Howard speeds up editing and deploys a much darker cinematography in comparison to the rest of the film in order to intensify the chaos and violence of the Hooverville.

At this point, some additional historical references need to be included in order to clarify the extent to which Howard's film effaces key legacies of the Roosevelt tradition. Popular reluctance to the Roosevelt administration existed during the 1930s, as New Deal historian Anthony Badger has noted (1989: 34-35). However, the political climate of the time differed from that represented and normalized throughout Howard's film. Roosevelt's own rhetoric may exemplify how class played a fundamental role during the Great Depression. In the 1936 presidential campaign, Roosevelt offered a much quoted indictment of the inequalities nurtured during the 1920s and 1930s:

We had to struggle with the old enemies of peace - business and financial monopoly, speculation, reckless banking, class antagonism, sectionalism, war profiteering. They had begun to consider the Government of the United States as a mere appendage to their own affairs. We know now that Government by organized money is just as dangerous as Government by organized mob. Never before in all our history have these forces been so united against one candidate as they stand today. They are unanimous in their hate for me - and I welcome their hatred. (Roosevelt 1936b)

In that same year, Roosevelt unequivocally likened poverty to a lack of freedom: "Necessitous men [sic] are not free men" (Roosevelt 1936a). "From 1936 to 
1944”, writes historian Michael Kazin “a class line stretched across presidential politics; urban wage earners of all ethnic origins overwhelmingly backed Roosevelt while their employers stuck with the GOP" (1995: 137). This historical and political background does not constitute the ideological basis of Cinderella Man, nor does it exert much influence in the themes of the film. Ultimately, engagement with class and political involvement appear as contextual elements that do not really drive or inform the protagonist's trajectory.

Implicit in the figure of Jim Braddock as a non-Rooseveltian hero lies the notion of the resilient subject - an element imbricated in neoliberal rationality. Resilience "connotes the capacity of a system to return to a previous state, to recover from a shock, or to bounce back after a crisis or trauma" (Neocleous 2013: 3). Cinderella Man is generously devoted to present Braddock undergoing a varied array of hardships - physical exhaustion, painful post-fight injuries, economic problems of all sorts, and socially embarrassing moments derived from his economic situation. Nonetheless, he eventually overcomes all those obstacles by resorting almost exclusively to his own resolve. This narrative mold is just another iteration of Puritan Manicheism - personal success and relentless effort as Americanism, personal failure as un-Americanism (Bercovitch 2011: xxxvii). Much as Jim Braddock may well be seen as yet another Horatio Alger-like character, he likewise embodies the resilient subject of neoliberalism. "Good subjects" writes Neocleous “will 'survive and thrive in any situation' [... Neoliberal citizenship is nothing if not a training in resilience as the new technology of the self: a training to withstand whatever crisis capital undergoes and whatever political measures the state carries out to save it" (2013: 5). The fact that Braddock's stoic endurance is his sole tool to overcome his precarious situation upholds, precisely, that vision whereby individuals' main resources to prosper ought to be personal autonomy, and the capacity to "operate $[. .$.$] in a context replete with risk, contingency, and potentially$ violent changes, from burst bubbles and capital or currency meltdowns to wholesale industry dissolution" (Brown 2016: 84).

The resilient subject helps transform the notion of class as obsolete insofar as human cohabitation is to be primarily understood as the interaction of autonomous citizens capable of drawing up individual plans, selecting sensible goals, and appropriately allocating resources (Dardot and Laval 2014: 107). This framework is repeatedly exercised by Braddock, who remains consistently reluctant to view class mobilization as a useful practice, and is strengthened by the very storyline of the film, which systematically renders groups of workers invisible and shows unionization as inefficient. This discourse also permeates other characters in the story such as Braddock's manager Joe Gould (Paul Giamatti). The audience is led to believe Joe is a well-off businessman; however, when Braddock's wife Mae 
(Rennée Zellweger) goes to Joe's house to learn about his plans concerning Braddock's fighting career, it is disclosed that Joe is bankrupt and lives in an almost empty apartment:

MAE: I didn't know. I mean, I thought that...

JOE: Yeah, no. That's the idea. Always keep your hands up. Sold the last of it two days ago. So Jimmy could train. (Howard 2005: min. 68)

Not only is the narrative of resilience and extreme sacrifice articulated through the character of Braddock. Joe's actions similarly reinforce the notion of resilience as the core trait of the self and the good citizen. He goes to enormous lengths to appear as if he has remained socioeconomically stable in order to back up Braddock and get him more fights. By means of different actions, both Braddock and Joe render resilience noble, heroic, and, ultimately, efficient.

\section{The Welfare State Encounters Neoliberalism}

Although the film displaces central features of the Great Depression, the narration cannot circumvent the issue of the federal government - both an indispensable element during the 1930s and the main object of excoriation in the agenda of neoliberalism:

The major theme of neo-liberalism has it that the bureaucratic state destroys the virtues of civil society - honesty, the sense of a job well done, personal effort, civility and patriotism. It is not the market that destroys society through the 'appetite for gain', for it could not function without these virtues of civil society. [...] The wellintentioned fight against poverty has failed because it has deterred the poor from striving to better themselves, unlike numerous generations of immigrants. Trapping individuals in depreciated categories, a loss of dignity and self-esteem, the homogenization of the poor class - these are some of the unintended consequences of social aid. (Dardot and Laval 2014: 164)

The reduction and retooling of state structures is, indeed, a touchstone argument for neoliberalism (Harvey 2005: 76-78; Peck 2010: 9-20). However, it would be extraordinarily difficult for a cultural text to make the case against the New Deal's aggrandizement of governmental power as a safeguarding strategy in the midst of the Great Depression. "It was during the New Deal era" writes Alex Waddan "that the federal government established itself as having the ultimate responsibility for the nation's socio-economic well-being" (2002: 6). The New Deal tradition is such an important cultural and political heritage that the film cannot but participate in some of its values. For instance, in some sequences, Braddock criticizes the wealthy for being careless and removed from the daily hardships of working class people (see Howard 2005: mins. 16-17, 95). 
Because of the common-sense potency of the New Deal within American culture, the film offers a middle-ground positioning regarding the federal government that fits its overall ideological disclosure and does not get to attack Roosevelt's sacrosanct legacy. In a moment of extreme need, Braddock obtains some financial aid from the Emergency Relief Administration - an agency reinvigorated by New Deal investments. The highly expressive score and mise-en-scène - a highangle framing followed by a tracking shot featuring a crowded government office - emphasize how dramatic and humiliating the moment is for Braddock, who is even recognized by the clerk handing him the money (Howard 2005: min. 39). While it would be farfetched to pin down this sequence per se as an indictment of the welfare system, it is later on that the film discloses a clearer neoliberal subtext. When he has recovered financially, Braddock returns the money to the treasury. In a public interview, when questioned about this issue, he answers as follows:

REPORTER: Two days ago, we ran a story about you giving your relief money back. Can you tell our readers why?

BRADDOCK: I believe we live in a great country. A country that's great enough to help a man financially when he's in trouble. But lately I have had some good fortune and I'm back in the black. And I just thought I should return it. (min. 89)

The ideological ambiguity of this narrative strand reveals a discourse that merges two different standpoints. There is the acknowledgement that some form of welfare coverage is necessary in certain moments of extreme social and economic peril. However, the protagonist's returning of the money indicates that accepting such aid as a legitimate right would be somewhat detrimental. The sequence simultaneously recognizes the legitimacy of the New Deal and casts doubt as to the whether its policies are fully moral and valid in the long run. Grindon sees an unresolved ambivalence in that regard since the film "shows compassion for the poor in representing the hardship of the Braddock family" but, at the same time, Braddock repaying his welfare money implies that "decent citizens should not look to the state for assistance in time of need. Having it both ways" continues Grindon "undermines the film, as its conflicts dissolve in Ron Howard's feelgood sensibility" (2011: Epilogue). Thus, the film incorporates the assumption that government assistance, albeit imperative at very specific times, ought not to be a normative model of action. Much as the policies of the New Deal are not explicitly questioned in the sequence, its ideological subtext is linked to political narratives that have equated Rooseveltian liberalism with well-intended yet ultimately dangerous un-American tendencies towards "intrusive big government" and debilitated "individual initiative and risk" (Wilentz 2008: 136). As opposed to that view on the federal government, in the last act of The Grapes of Wrath, the 
Joad family arrives at a well-equipped camp efficiently and humanely run by the Department of Agriculture, where corrupt policemen and businessmen are denied access. Ford's film is not nearly as middle-of-the-road in their support of government intervention as Howard's. While Cinderella Man sees the role of government as somewhat necessary yet not fully legitimate, The Grapes of Wrath is considerably less ambiguous in its Keynesian message: in moments of great need the federal government must act upon the economy, highlighting the main political prescription of the New Deal: "What the New Deal did [...] was create an expectation that government could and therefore would act to sweeten the economy" (Waddan 2002: 32).

\section{Cinderella Man as a 'New Democrats' Cultural Text}

There is yet another reading concerning domestic American politics and one of its most recent realignments. As examined in previous sections, Cinderella Man does not explicitly indict the New Deal but neither do Roosevelt's policies inform the film as a political and cultural text. At best, FDR and the old-style Democratic Party are nominally accepted. There are, however, instances where the film seemingly embraces the language of class. Before the final fight for the heavyweight championship, Braddock is warned that his final opponent and current heavyweight champion Max Baer (Craig Bierko) has killed some boxers in the ring. Braddock answers as follows:
You think you're telling me something? What, like, boxing's dangerous, something like that? You don't think triple shifts or working nights on the scaffolds is just as likely to get a guy killed? How many guys died the other night living in cardboard shacks trying to save on rent money? Guys who were trying to feed their family. 'Cause men like you have not yet quite figured out a way to make money out of watching that guy die. In my profession, and it's my profession I'm a little more fortunate. (Howard 2005: min. 95)

However, the analysis offered in previous sections, as well as the occasional comparisons with The Grapes of Wrath, have made it clear that the ideological narratives underpinning Howard's film do not originate in the Rooseveltian tradition.

It is my argument that Cinderella Man draws on the political culture of the New Democrats - a faction within the Democratic Party revolving around the presidency of Bill Clinton (1993-2001). Clintonism sought to develop more centrist political positions while appropriating certain elements from the conservative hegemony of the 1980s. ${ }^{5}$ During the 1970 s and 1980s, a significant number of Democrats became increasingly reluctant to acknowledge New Deal 
liberalism as their political tradition. In public discourse the notion of an active federal government - the very foundation of New Deal liberalism - became tantamount to onerous taxation, bureaucracy, and wasteful and inefficient welfare programs (Aronowitz 1992: 422; Berman 1998: 57; Troy 2004: 68), as then-candidate Ronald Reagan so famously encapsulated in the 1980 presidential debate: "Government is not the solution to our problems, government is the problem" (Reagan 1980), initiating a twelve-year period of Republican presidencies. This was the context for well-known moments in recent political history for the Democratic Party such as 1988 Democratic presidential candidate Michael Dukakis strenuously and repeatedly claiming he was not a liberal (Depoe 1997: 100-104) or Bill Clinton announcing in the 1996 State of the Union Address "the end of big government" (Clinton 1996) - using the very same vocabulary Reaganism had deployed throughout the 1980 s to indict the politics of postwar liberalism.

Faced with the fact that conservatism had become hegemonic, a group of politicians and intellectuals within the Democratic Party - most of them associated with the Democratic Leadership Council- assumed that some form of political readjustment was needed in order to counteract the anti-government, anti-liberal narratives legitimized during the Reagan years. The DLC's thesis was that "the Democratic Party could only win if it moved 'to the center', severing ties with its constituent groups and embracing certain free-market policies of the right" (Frank 2016: 57). Given that Reaganism had transformed conservatism into the hegemonic language and practice of American politics, Democrats were to accommodate into that landscape:

[Clinton's] claim was that he was a Democrat who recognized that there was no going back to the old days, good or bad depending on perspective, of the New Deal and Great Society. [...] So just as Eisenhower had not tried to repeal the New Deal and as Nixon had accepted the continued expansion of the American welfare state so too Clinton was bound to find an accommodation with elements of the Reagan legacy. (Waddan 2002: 10)

This gave way to the famous politics of triangulation during the 1990s whereby Democrats were to combine class-inspired rhetoric to retain some of their historical constituents while enacting policies favorable to corporate interests (Nichols and McChesney 2013: 32). The principal implication of the New Democrats' approach was that the New Deal had become an obsolete political guideline: "Democrats could no longer be the party of Franklin Roosevelt's New Deal coalition, with its heavy reliance upon labor and its tendency to see issues through the lens of social class. [...] [T]he Great Depression - the period that formed the identity of the Democratic Party - was a far-off country suffering 
from incomprehensible troubles. The New Deal was quickly becoming irrelevant" (Frank 2016: 44-49).

Cinderella Man is nothing if not a reinforcement of the assumptions underpinning the politics of the New Democrats. The Rooseveltian tradition is obviously present and plays a role in the story but its political prescriptions and languages do not inform the protagonist's quest. Although there might be occasional praise for FDR and the welfare state is not flatly condemned, the core contents of the New Deal are not upheld or legitimized, let alone celebrated. In light of the analysis performed, and the themes and discourses pointed out, Jim Braddock stands for individualism, resilience, and reluctance to view class as an identity vector. Class consciousness, government interventionism, a critical stance towards big business and exploitation, and grassroots mobilization - the basic constituents of the New Deal and the FRD tradition- may well be acknowledged along the story but these do not constitute the discourse of the film.

Howard's film ends with Braddock winning the heavyweight championship in a historic upset, culminating the narrative of the resilient underdog. It seems worth referencing for the last time The Grapes of Wrath, in this case, some extracts from the famous last speech by Tom Joad:

I've been thinking about us too. About our people living like pigs and good, rich land laying fallow. Or maybe one guy with a million acres and 100,000 farmers starving. And I've been wondering if all our folks got together and yelled [...] Well, maybe it's like Casy says. Fella ain't got a soul of his own, just... a little piece of a big soul. The one big soul that belongs to everybody. [...] I'll be all around in the dark. I'll be everywhere wherever you can look. Wherever there's a fight so hungry people can eat, I'll be there. Wherever there's a cop beating up a guy, I'll be there. I'll be in the way guys yell when they're mad. I'll be in the way kids laugh when they're hungry and they know supper's ready. And when the people are eating the stuff they raise and living in the houses they build I'll be there too. (Ford 1940: mins. 120-122)

It is unthinkable that Jim Braddock should utter such a communalist and classinfused speech at the end of Cinderella Man because the Rooseveltian language is not his political background. His is shaped by a different set of values and by a different Democratic Party —one premised upon a central narrative Thomas Frank has summed up as follows:

What workers need $[\ldots]$ is to be informed that $[\ldots]$ there's nothing anyone can do to protect them. That resistance is futile. That only individual self-improvement is capable of lifting you up - not collective action, not politics, not changing how the economy is structured. (2016: 68) 


\section{Conclusion}

Cinderella Man is not a Rooseveltian film. The New Deal and its political culture are not really celebrated in the film, nor do they seem to be shown as completely legitimate. However, Howard's film is not Manichean or extremely partisan in articulating its discourse. This is so because, despite the hegemonic status of neoliberalism, hegemony does not function along starkly and one-dimensionally ideological lines. As Stuart Hall had it, "[c]ultural hegemony is never about pure victory or pure domination $[\ldots][\mathrm{I}] \mathrm{t}$ is never a zero-sum cultural game; it is always about shifting the balance of power in the relations of culture; it is always about changing the dispositions and the configurations of cultural power not getting out of it" (1996: 471). Thus, a neoliberal film such as Cinderella Man does not flatly neglect or demonize the political and cultural legacy of the New Deal. Instead, the film inscribes the narratives of neoliberalism in fundamental aspects of the storyline - framing critical issues such as class, the individual, and the state so that these cohere with neoliberal values - while retaining a series of iconographies related to Rooseveltian liberalism and mainstream conceptions of Americanism. Images of the working class, poverty, state-run agencies, and comments against the well-off do appear but these do not sustain and articulate the discourse of the film.

What this paper has ultimately sought to understand is how political and cultural meanings can be renegotiated and rearticulated in film, in this case, how neoliberalism may tap into imaginaries historically and culturally bound up with Rooseveltian liberalism. Any period from history may be narratively and ideologically patterned so that specific sets of symbols and rationales are enshrined while others are rendered secondary. In this sense, I have argued that Cinderella Man integrates the narratives of neoliberalism into a period of central significance for American progressivism and working class mobilization. The Great Depression is hegemonized in this film by neoliberalism. Thus, the ideological readability (Žižek 2008: 15) of Cinderella Man impels the audience to make sense of the Great Depression through the neoliberal subject. In so doing, the film constructs an ideological framework that diminishes the role of the systemic elements in economic crises and promotes individuals' responsibility as the main driving force that may bring about solutions. In George Orwell's 1984 one of the slogans of The Party reads as follows: "who controls the past controls the future" (1990: 37). The hegemonic rewriting of history through cultural texts may well prove Orwell' point since, as Cinderella Man exemplifies, present-day hegemonies and legitimacies can be further reasserted and reinforced on the basis of re-narrating the past. 


\section{Notes}

\begin{abstract}
1. This paper is part of the Research Project "Justice, Citizenship and Vulnerability: Precarious Narratives and Intersectional Approaches" (FFI2015-63895-C2-1-R), funded by the Spanish Ministry of Economy and Competitiveness.

2. For a periodization of the stages of neoliberalism see Harvey (2005: 5-38) and Peck (2010: 1-38).

3. A clarifying note needs to be included so that the theses defended in the article can be intelligible. In American English the word "liberalism" alludes to the political left or center left -the usage I will stick to when referring to Roosevelt's legacy. "It was the Keynesian advocacy of an interventionist state and regulated markets", explain Steger and Roy, "that gave 'liberalism' its modern economic meaning: a doctrine favouring a large, active government, regulation of industry, high taxes for the rich, and extensive social welfare programmes for all" (2010: 8-9). For Europeans, on the other hand, "liberals"
\end{abstract}

are usually thought to be advocates of antistatist laissez faire (Lipset 1996: 36). The term neoliberalism encapsulates this latter meaning, that is, a market-oriented reaction against social democracy and its American equivalent (i.e. liberal New Deal-inspired policies). In the United States neoliberal policies have been referred to as deregulation.

4. David Bordwell has established that classical Hollywood films tended to make "history unknowable apart from its effects upon individual characters" (1985: 13). In turn, modern Hollywood filmmaking largely applies the same core narrative techniques and plot patterns classical films did (Bordwell 2006: 50).

5. The realignments within the Democratic Party from the Carter Administration until the Clinton years can be revised in Berman (1998: 164-187), Frank (2016: 62-105), Waddan (2002: 1-43), and Wilentz (2008: 323381).

\section{Works cited}

Aronowitz, Stanley. 1992. False Promises: The Shaping of American Working Class Consciousness. Durham: Duke U.P.

BADGer, Anthony J. 1989. The New Deal: The Depression Years, 1933-1940. London: McMillan Education.

Bercovitch, Sacvan. (1975) 2011. The Puritan Origins of the American Self. New Haven:Yale U.P.

Bergman, Andrew. 1971. We're in the Money: Depression American and its Films. Chicago: Ivan R. Dee.

Berman, William C. 1998. America's Right Turn: From Nixon to Clinton. Baltimore: Johns Hopkins U.P.
Bordwell, David. 1985. "Part One: The Classical Hollywood Style, 1917-60". In Bordwell, David, Janet Staiger and Kristin Thompson (eds.) The Classical Hollywood Cinema: Film Style and Mode of Production to 1960. London: Routledge: 1-84.

Bordwelt, David. 2006. The Way Hollywood Tells It: Story and Style in Modern Movies. Berkeley: University of California Press.

Brown, Wendy. 2016. Undoing the Demos: Neoliberalism's Stealth Revolution. Cambridge: Zone Books.

CaZDYN, Eric. 2007. “Disaster, Crisis, Revolution". South Atlantic Quarterly 106 (4): 647-662. 
Christensen, Terry. 1987. Reel Politics: American Political Movies from Birth of a Nation to Platoon. New York: Basil Blackwell.

Clinton, Bill. 1996. "1996 State of the Union Address". The American Presidency Project <https://www.presidency.ucsb.edu/ documents/address-before-joint-session-thecongress-the-state-the-union-10>. Accessed October 24, 2018.

ComA, Javier. 2007. Las Películas de la Caza de Brujas. Madrid: Notorious Ediciones.

DARdot, Pierre and Christian LaVAL. 2014. The New Way of the World: On Neoliberal Society. Trans. G. Elliot. New York: Verso.

Depoe, Stephen. 1997. Arthur Schlesinger, Jr., and the Ideological History of American Liberalism. London: University of Chicago Press.

Díaz Salazar, Rafael. 1991. El Proyecto de Gramsci. Madrid: Anthropos.

Ford, John. 1940. The Grapes of Wrath. 20 ${ }^{\text {th }}$ Century Fox.

Formisano, Ronald P. 2015. Plutocracy in America: How Increasing Inequality Destroys the Middle Class and Exploits the Poor. Baltimore: Johns Hopkins U.P.

FRANK, Thomas. 2016. Listen, Liberal! Or Whatever Happened to the Party of the People? London: Scribe Publications.

Freeden, Michael. 2015. Liberalism: A Very Short Introduction. New York: Oxford U.P.

FukuYama, Francis. (1992) 2012. The End of History and the Last Man. London: Penguin.

Gramscl, Antonio. (1971) 1991. Selections from the Prison Notebooks. Ed. and trans. Q. Hoare and G. Nowell Smith. London: Lawrence and Wishart.

Grindon, Leger. 2011. Knockout: The Boxer and Boxing in American Cinema. Jackson: University Press of Mississippi. E-Book.

HaLL, Stuart. 1996. "What is this 'Black' in Black Popular Culture?" In Morsley, David and Kuan-Hsing Chen (eds.) Stuart Hall: Critical Dialogues in Cultural Studies. London: Routledge: $468-478$.
Harvey, David. 1990. The Condition of Postmodernity: An Enquiry into the Origins of Cultural Change. Oxford: Blackwell.

Harvey, David. 2005. A Brief History of Neoliberalism. Oxford: Oxford U.P.

Hobsbawm, Eric. 1994. Age of Extremes: The Short Twentieth Century 1914-1991. London: Abacus Books.

Howard, Ron. 2005. Cinderella Man. Universal Pictures.

Junco Ezouerra, Víctor Manuel. 2003. “La Guerra de Dos Mundos: Identidad y Otredad en el Discurso Político y Cultural de la Guerra Fría en Estados Unidos, 1945-1953". PhD Dissertation. Universidad de La Laguna.

Kazin, Michael. 1995. The Populist Persuasion: An American History. New York: Basic Books.

LIPSET, Seymour M. 1996. American Exceptionalism: A Double-Edged Sword. New York: W.W. Norton and Company.

Morgan, Iwan. 2016. "John Ford's Young Mr. Lincoln: A Popular Front Hero for the Late 1930s". In Morgan, Iwan, and Philip John Davies (eds.) Hollywood and the Great Depression: American Film, Politics and Society in the 1930s. Edinburgh U.P.: 257-276.

Neocleous, Mark. 2013. "Resisting Resilience". Radical Philosophy 178 (March/April): 2-7.

Nichols, John and Robert W. McChesney. 2013. Dollarocracy: How the Money and Media Election Complex is Destroying America. New York: Nation Books.

OrWELL, George. (1949) 1990. Nineteen EightyFour. London: Penguin Books.

Patterson, James T. 2010. “Transformative Economic Policies: Tax Cutting, Stimuli, and Bailouts". In Zelizer, Julian (ed.) The Presidency of George W. Bush: A First Historical. Princeton: Princeton U.P.: 114-138.

PECK, Jamie. 2010. Constructions of Neoliberal Reason. Oxford: Oxford U.P.

Reagan, Ronald. 1980. "1980 Carter-Reagan Debate". Commission on Presidential Debates. <http://www.debates.org/index.php?page= october-28-1980-debate-transcript>. Accessed October 14, 2018. 


\section{Fabián Orán Llarena}

Roosevelt, Franklin D. 1936a. "Acceptance Speech for the Renomination for the Presidency, Philadelphia, June 27, 1936". The American Presidency Project. <https://www. presidency.ucsb.edu/documents/ acceptance-speech-for-the-renomination-forthe-presidency-philadelphia-pa>. Accessed October 24, 2018.

Roosevelt, Franklin D. 1936b. "Address at Madison Square Garden, New York City, October 31, 1936". The American Presidency Proyect. <https://www.presidency.ucsb.edu/ documents/address-madison-square-gardennew-york-city-1>. Accessed October 14, 2018.

Steger, Manfred B., and Ravi K. Roy. 2010. Neoliberalism: A Very Short Introduction. New York: Oxford U.P.

THATCHER, Margaret. 1987. “Interview by Douglas Keay". Woman's Own. <https://www. margaretthatcher.org/document/106689>. Accessed August 7, 2017.

Troy, Gil. 2004. Morning in America: How Ronald Reagan Invented the 1980s. New Jersey: Princeton U.P.

Received: 11 October 2017

Accepted: 07 July 2018
VIDoR, King. 1934. Our Daily Bread. United Artist.

Waddan, Alex. 2002. Clinton's Legacy? A New Democrat in Governance. New York: Palgrave.

Wells, Wyatt. 2003. American Capitalism, 1945-2000. Chicago: Ivan R. Dee.

Wheeler, Mark. 2016. “The Political History of Classical Hollywood: Moguls, Liberals and Radicals in the 1930s". In Morgan, Iwan, and Philip John Davies (eds.) Hollywood and the Great Depression: American Film, Politics and Society in the 1930s. Edinburgh U.P.: 2948.

WilentZ, Sean. 2008. The Age of Reagan: A History, 1974-2008. New York: Harper.

ZInN, Howard. 2003. A People's History of the United States. New York: Harper Perennial Modern Classics.

ŽıŽEK, Slavoj, 2008. En Defensa de la Intolerancia. Trans. J.E. Ceballos and A.J. Fernández. Madrid: Ediciones Sequitur. 